The glycoproteins were dealt with by Prof. C. Rimington, who defined these substances as proteins which contain carbohydrate groups in chemical combination as an integral portion of the molecule. According to the classification of Blix, acidoglycoproteins and neutroglycoproteins may be distinguished. Confining attention to the latter class, Prof. Rimington pointed out that by the methods ordinarily employed for the preparation of proteins, it is very difficult to get rid of carbohydrate impurities and that all possible criteria of purity should be applied to any preparation before it is concluded that it is, in fact, a glycoprotein. Five criteria of general spplicability were listed, namely, (1) constancy of composition, (2) electrophoretic homogeneity, (3) ultracentrifugal homogeneity, (4) independence of solubility upon the amount of solid phase, and (5) constant potency in the case of materials exerting a measurable physiological effect; a number of glycoproteins for which recognition has been claimed were then examined in the light of their conformity to these criteria.

The presence of a polysaccharide in serum albumin was first demonstrated by Rimington, but Sørensen in his classical work on this protein showed that it does not obey criterion (4), a whole series of crystalline albumins being obtainable which differ in their solubilities and in their carbohydrate contents. McMeekin has claimed the isolation of crystalline serum albumin containing $\mathbf{5 \cdot 5}$ per cent carbohydrate, which he considered was a single substance since it was apparently homogeneous both in the ultracentrifuge and in the electrophoresis apparatus. The further test of constant solubility was not applied, however, and in view of the behaviour of the serum gonadotrophin, this final criterion would seem necessary.

Much careful work has been done upon the protein hormones of the anterior lobe of the pituitary gland, and these substances are among the best characterized of protein preparations. The luteinizing gonadotrophin or metakentrin has been obtained in a form satisfying all available criteria of purity and containing 4.5 per cent of carbohydrate (from sheep glands) ; it is thus a well-authenticated glycoprotein.

The gonadotrophin of pregnant mares' serum has not yet been obtained in such a satisfactory condition; Rimington and Rowlands found material with an activity of 3,500 r.v./mgm. to be electrophoretically and ultracentrifugally homogeneous, but further fractionation with acid alcohol raised the potency to 12,500 I.U./mgm. without at the same time appreciably altering the carbohydrate content. It seems quite clear that one must here be dealing with a mixture or mutually reacting system of very closely related glycoproteins only some of which possess gonadotrophic activity, and this experience prompts \& warning against accepting as homogeneous any glycoprotein (especially if derived from serum) which has not satisfied all criteria of purity which can be applied to it.

Dr. W. T. J. Morgan reviewed our chemical knowledge of the blood group substances and pointed out that the polysaccharide components of the $A, B$ and $O$ agglutinogens are similar if not identical, so that differences must be in the polypeptide part of the molecule. Besides $\mathrm{N}$-acetylglucosamine and $d$ galactose. they are said to contain $l$-fucose and $d$ mannose.

A very interesting reaction occurs when these glycoproteins are heated at $100^{\circ}$ for 3-4 min. in very dilute alkali; a portion of the $\mathrm{N}$-acetylglucosamine residues becomes detached and dialysable and in the alkaline medium, through ring closure between the aldehyde and $\mathrm{N}$-acetyl groups, oxazole or oxazoline derivatives are formed which give a red colour directly with Ehrlich's reagent. Clearly the mechanism of this reaction is of no little importance for an understanding of the structure of the polysaccharide complex, and lively discussion centred about it. Dr. Morgan considers that the alkali labile linkages are probably glycoside linkages which are associated with $\mathrm{C}$ atom $\mathrm{I}$ of the $\mathrm{N}$-acetylglucosamine residues.

The enzymes attacking amino-sugar and uronic acid polysaccharides were considered by Dr. H. J. Rogers, from whose survey it was clear that a cardinal difficulty in this field has been the separation of individual enzymes from crude extracts. This has been especially noticeable in the case of hyaluronidase, where the end-products produced from hyaluronic acid have been shown to differ according to the source of the enzyme.

In the final communication, Prof. G. F. Marrian described the steroid glucuronides which have so far been isolated from urine, and the methods by which the position of attachment of the uronic acid residue has been deduced. It is noteworthy that crystalline sodium pregnanediol glucuronidate prepared from human pregnancy urine has been found to contain about 15-20 per cent of an impurity believed to be sodium pregnane-3( $\alpha)$-ol-20-one glucuronidate, but which cannot be removed by the usual methods of purification. Similarly, the sodium salt of pregnane$3(\alpha), 17,20$-triol glucuronidate cannot be separated from sodium pregnane-diol glucuronidate by any of the usual purification procedures.

The possible functions of the enzyme $\beta$-glucuronidase were discussed and also the various steps by which the biosyntheses of the glucuronides might be accomplished.

\section{CALCAREOUS CONCRETIONS IN A CAMBRIDGESHIRE STREAM}

\author{
By Prof. F. E. FRITSCH, F.R.S., and \\ DR. C. F. A. PANTIN, F.R.S.
}

$\mathrm{D}^{2}$

URING the exceptional drought of 1943, the Bourne Brook, a stream which enters the River Cam near Grantchester, was, except for the last mile of its course, without water for the first time for many years. In the lower reaches of the dry bed there were numerous dead Anodonta cygnea and small fish. Normally the Bourne consists of long pools, about $8 \mathrm{ft}$. across and $2 \mathrm{ft}$. deep with a bottom of mud and clay, joined by shallow runs which in summer are usually filled with aquatic vegetation. The pools, on the other hand, generally contain no higher plants and are often deeply shaded by bushes.

The dry bottom of these pools presented a remarkable sight, being strewn with coral-like nodules 2$20 \mathrm{~cm}$. in diameter (Fig. 1) resting on the mud. These nodules ranged in colour from pale grey-green in damp specimens to a dirty white in dry ones. When broken open each nodule contained a foreign nucleus around which friable calcareous material had evidently been deposited. The nucleus was commonly a pebble, a piece of water-logged wood or a molluscan shell. Anodon shells were found with all stages of the calcareous growth upon them and similar material 


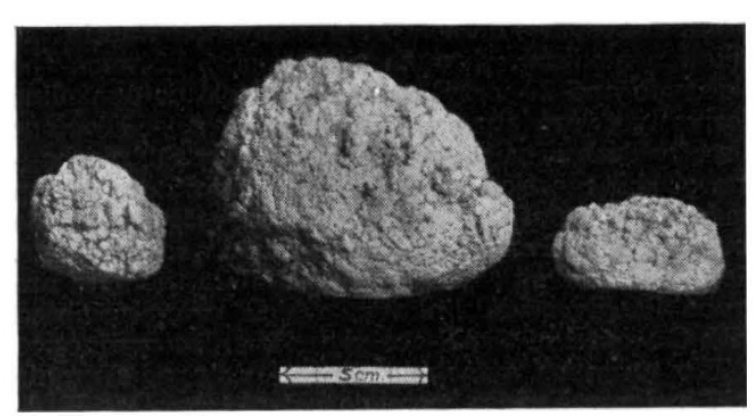

Fig. 1.

encrusted a small concrete dam across the river. Fig. 2, which represents a nodule cut across exposing its flint nucleus, shows the layered character of the celcareous growth.

The deposition of the nodules is undoubtedly associated with the presence of blue-green algæ, to which, indeed, the greenish tint of freshly dredged specimens is due. The principal species found in them is Phormidium incrustatum (Naeg.) Gom., which is known to be concerned in lime deposition and has not previously been recorded for Britain. The larger growths are raised into many rounded bosses of various sizes and laterally confluent with one another. The outer convex surface of each boss usually shows a series of low curving ridges surrounding shallow angular depressions.

Decalcification of a boss in 1 per cent hydrochloric or acetic acids proceeds slowly for some days. The rather soft gelatinous mass that remains, when all the lime has been removed, is of the same size as the original boss. A longitudinal section shows that a greenish tint is only present in the relatively tough surface layer, which is about $1-1.5 \mathrm{~mm}$. thick. The whole interior appears white and rather crumbly. The colourless mucilage, which envelops the numerous Phormidium filaments and forms the basis of the gelatinous growth, contains a good deal of incorporated silt. In the greenish surface layer, the sheaths of the densely packed Phormidium filaments are largely occupied by trichomes, while in the interior of the decalcified mass for the most part only empty sheaths are found. The relatively small number of

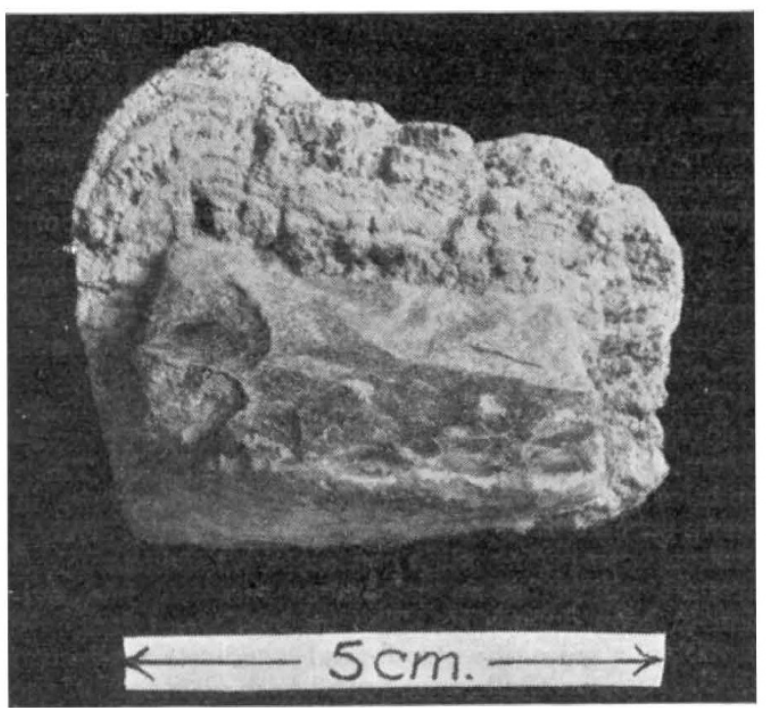

Fig. 2. these sheaths in the interior suggests that some may have already undergone decay. In the outer living part most of the filaments are arranged approximately parallel to one another and at right angles to the surface. Abundant hormogone formation takes place from the outer ends of the filaments. Buried in the stratum are diverse foreign bodies (fragments of coniferous wood, spiral vessels, threads of $Q E$ dogonium, etc.), as well as occasional small growths of other bluegreen algæ, some of them retaining their vivid blue colour.

If one of the bosses is kept in 1 per cent acetic acid for about twenty hours, decalcification only sets in in the surface layer, which can be peeled off the hard remaining portion like a skin. If the outer surface of this skin is viewed from above, one sees projecting filaments of Phormidium which probably represent the initiation of a new increment on the surface of the nodule. The edge of the skin presents a striated appearance as a result of the parallel arrangement of the contained trichomes.

The growth on the dam was not so pure, but also consisted to a large extent of calcified $P$. incrustatum, although the stratum was here relatively thin with the filaments of the alga irregularly arranged and densely compacted. This is probably an earlier stage in which the characteristic bossed growths have not yet developed. Intermediate conditions occurred on a shell of Anodon, where some bosses were becoming evident.

The calcified growths also include tufts of a green alga, a species of Gongrosira, which in places are quite plentiful, in others altogether lacking. Diverse species of Gongrosira are known to occur in streams and some of them deposit lime. The very irregular occurrence of these tufts, however, suggests that they are just growths of Gongrosira that have become buried in the Phormidium-stratum (like the other foreign bodies mentioned above) and their complete absence in certain parts of the nodules indicates that they are probably not in any way responsible for their formation.

These calcareous growths recall more or less similar concretions found in lakes in various parts of the world ${ }^{1}$; but there is only one previous record of their occurrence in streams. H. J. Roddy ${ }^{2}$ describes from the Little Conestoga Stream, Lancaster County, Pa., nodules which in physical characters and mode of occurrence seem to resemble exactly those found in the Bourne.

Dr. D. Stockdale kindly gave us the following analysis for one of the dried Bourne Brook specimens. The values for Little Conestoga specimens are calculated from Roddy's figures.

\begin{tabular}{|c|c|c|c|c|}
\hline & Bourn & Brook & Little Con & estoge \\
\hline $\mathrm{SiO}_{2}$ & $\begin{array}{l}4 \cdot 75 \\
0 \cdot 66\end{array}$ & c cent & $12 \mathrm{pe}$ & cent \\
\hline $\mathrm{P}_{2} \mathrm{O}_{5}$ & $0 \cdot 15$ & $"$ & 一 & \\
\hline $\mathrm{CaO}$ & $48 \cdot 55$ & $"$ & $39-45$ & \\
\hline $\mathrm{Fe}_{2} \mathrm{O}$, & 0.94 & ” & 3 & ” \\
\hline $\mathrm{Al}_{2} \mathrm{O}_{3}$ & $1 \cdot 78$ & $"$ & trace & \\
\hline MgO & 0.05 & ", & trace to 0.5 & " \\
\hline $\mathrm{H}_{2} \mathrm{O}$ (at $105^{\circ} \mathrm{C}$.) & $1 \cdot 22$ & ", & 1 & ," \\
\hline $\begin{array}{l}\mathrm{CO}_{3} \\
\text { Organic matter }\end{array}$ & $37 \cdot 29$ & ", & $31-35$ & $"$ \\
\hline & & & & , \\
\hline
\end{tabular}

Roddy found the nodules also in a few noighbouring streams, but only in those with a high content of dissolved salts, presumably calcium carbonate. Cam. bridgeshire waters are generally rich in calcium carbonate, and nodules similar to those of the Bourne Brook have been found by us in other local streams, such as the Linton River and Hobson's Brook, though not, up to the present, in the River Cam itself. These 
other streams rise in the chalk and are therefore heavily impregnated with lime, but curiously enough the nodules are much less developed in them than in the Bourne Brook, which flows over gravels, clays and the greensand, west of the chalk escarpment. This suggests that factors other than lime content of the water may also be important. It is noteworthy that the Bourne Brook is more apt to become fouled with organic matter from agricultural land than the other streams.

The chief apparent difference between the Bourne Brook and Little Conestoga nodules rests in the Algæ recorded from them. Roddy attributes the precipitation of calcium carbonate to a number of blue-green Algæ and records Gloeocapsa, Gloeothece, A phanocapsa, Nostoc, Oscillatoria and Rivularia, but not Phormidium. It would be of interest to know whether, in spite of the physical similarity, the nodules are produced by different genera of Algæ in the only two cases on record.

${ }^{1}$ Fritsch, F. E., "Structure and Reproduction of the Algø", 2, 868 (1945).

'Roddy, H. J., Proc. Amer. Phil. Soc., 54, 246 (1915).

\section{OBITUARIES}

\section{Prof. J. Lloyd Williams}

Emeritus Professor John Lloyd Williams, of Aberystwyth, died on November 15, 1945. A native of Llanrwst, he entered the Normal College, Bangor, to prepare himself for a teaching career. An inveterate reader, a patient observer of Nature and her ways, a true lover of the open air, he was one of a group of distinguished North Wales botanists of his time, and contemporary with Dr. Trow, later professor of botany and principal of University College, Cardiff, and Prof. Phillips, who became professor of botany at Bangor. Soon after leaving college, Dr. Lloyd Williams was appointed master of Garn Dolbenmaen Board School, where in addition to his school duties he pursued his botanical studies and continued to develop the musical talent which made him prominent in eisteddfod circles, both as a choir conductor and an adjudicator.

Eventually Dr. Lloyd Williams returned to Bangor, where he studied in the University College of North Wales, and graduated in the faculty of science in 1906; he was afterwards appointed to a lectureship on the staff of the Botany Department of the College. In those days, the Botany Building at Bangor was almost lapped by the waves; and under Prof. Phillips, Dr. Lloyd Williams' enthusiasm for the study of marine plants became manifest. Later, under Sir John Farmer, Dr. Lloyd Williams continued his investigations at the Imperial College, London, and began his important contributions to the life-history of the brown seaweeds. $\mathrm{He}$ was appointed to the chair of botany at Aberystwyth in 1916, where he was ideally placed for the continued study of marine plants. He was honoured by his colleagues by being made president of Section $\mathrm{K}$ (Botany) of the British Association at the Southampton meeting in 1925, and he did not resign the chair of botany at Aberystwyth until 1926, when he was seventy-one years of age. Prof. Lloyd Williams was a great teacher and a true naturalist. He endeared himself to his students, and in them his enthusiasm for the subject is reflected. To him, the field of Nature was the great laboratory, and work indoors was a corollary to that primary mode of investigation.
It is not given to many individuals to be specialists in more than one field of study, but Prof. Lloyd Williams had attained that distinction. In 1936, he became an honorary doctor of music of the University in which he already held a D.Sc. degree. He was jointly responsible, with Dr. Mary Davies, for the foundation of the Welsh Folk Song Society, and from its inception he retained the editorship of the Journal of that Society. He journeyed throughout Wales to collect the old melodies, and in addition to arranging those for publication, he composed two operettas, one of which, "Llew Tegid", attained great popularity.

During the War, Prof. Lloyd Williams wrote his autobiography, "Atgofion Tri Chwarter Canrif", published by Gwasg Aberystwyth, a work which was very well received. Second and third volumes followed, and at the time of his death he was busily revising proofs of the fourth volume. In these interesting books, Prof. Lloyd Williams recalls the memories of his early days. It was through indomitable courage, ability and high ambition that he was able to pursue the subjects for which he cared. $\mathrm{He}$ retained those interests until the close of his long life, and when approaching his ninetieth year, he visited the Cader Idris range to see again some rare plant. Possessed of a wealth of knowledge, a clear voice, a pleasant smile and ready wit, Prof. Lloyd Williams endeared himself to those with whom he came in contact. His influence in his department and in Wales remains, though with his passing we have lost a great and distinguished son of the Principality.

LILY NewToN.

\section{Dr. J. C. Mottram}

J. C. MotTram was born at Holt, Norfolk, in 1880 and educated at The Beacon, Sevenoaks. He entered University College, London, in 1898, and five years later graduated in medicine. After a period of postgraduate study at Cambridge he took the D.P.H. in 1906. In the Cancer Research Laboratories of the Middlesex Hospital he worked in collaboration with Prof. Sidney Russ, and later was appointed director of the Research Department of the Radium Institute. With the inception of the Mount Vernon Hospital as a cancer hospital in 1931, he became its senior pathologist and director of pathological research, which position he held until his death on October 4.

Mottram's earlier work was devoted principally to the technique of radiotherapy. He did valuable work on the protection of X-ray workers, and served on the Radium and X-ray Protection Committee. Later he was concerned mainly with the problem of carcino. genesis. He was a man of very wide interests-a keen field naturalist, an expert fly fisherman of interna. tional repute, and an able water-colour artist, as well as an outstanding figure in cancer research.

His experience as a field naturalist and artist found practical application in the First World War, when he was appointed experimental officer in the Camouflage School of G.H.Q. He was the author of the article on natural camouflage in the "Encyclopædia Britannica" (12th edition, 1922). Another product of his interest in natural history was a book on "Controlled Natural Selection".

Mottram's wide biological outlook greatly influenced his approach to the study of cancer. For his investigations he employed a variety of organisms. Whichever seemed most suitable for the solution of the problem in hand, that was the one he employed, and 